\title{
RESEARCH ARTICLE \\ Screening Potential of Electrogenic Algae for Bio Power Production from Aquatic Habitats of Tamil Nadu
}

\author{
Sikkandhar Wasimraja ${ }^{1}$, Subburamu Karthikeyan*1,2, Kalyanasundaram Geetha \\ Thanuja $^{1}$
}
${ }^{1}$ Department of Agricultural Microbiology, Tamil Nadu Agricultural University, Coimbatore-641 003, India
${ }^{2}$ Department of Renewable Energy Engineering, Tamil Nadu Agricultural University, Coimbatore-641 003, India

*Corresponding author : skarthy@tnau.ac.in

\begin{abstract}
- This paper illustrates the potential ofmicroalgae in electricity production.The present study focuses on searching for, indigenous microalgal strains from various aquatic sources exhibiting electrogenic activity. Sixteen microalgal strains were obtained from the diverse water bodies and assessed for electron transfer ability between cell and electrode. Six algal strains were screened out of eighteen for potential electrogenicity, based on cyclic voltammetry assay. In contrast to other algal strains, the cyclic voltammograms of Hindakia sp. isolated from paddy fields displayed an oxidation peak under anaerobic conditions in the potential range of +100 to $+200 \mathrm{mV}$, while no distinct peaks were observed in other strains. This research broadened the exoelectrogen and identified model microalgae for investigating the extracellular electron transport process.
\end{abstract}

Keywords: Microalgae; Electrogenic; Cyclic Voltammetry;Hindakia sp.

\section{INTRODUCTION}

The continuous demand for energy across the globe coupled with the contribution to global warming deserves an alternate sustainable energy source. The discoveries of microbes that produce electricity from wastes represent an emerging technology of interest. The microbial systems are being employed in the production of electricity from various organic wastes with the simultaneous production of valuable chemicals and are termed as Bio-Electrochemical Systems (BES). It can use light energy to provide power and treat wastewater with the support of electro-active microorganisms (Oh and Logan, 2005). Microalgae have been widely recruited as BES in light of phototrophic microorganisms serves as in-situ generators of oxygen that ease reaction in the electrochemical process. Further, they are potential feedstock for a wide range of hydrocarbons (Rajesh et al., 2020) including biofuels, including methane, bio-oil, methanol, bio-hydrogen (Medipally et al., 2015; Zhou et al., 2015)

As one of the most common microorganisms, microalgae utilize solar energy to divide the water and provide electrons and oxygen. As BES, microalgae can utilize organic matter upon consuming carbon 
dioxide on an electrode surface yielding energy by metabolic activity (Lovley and Nevin 2011). Several potential activities including nitrogen and phosphorus absorption (Li et al., 2010), biodiesel synthesis, and biomass supply (Chen et al., 2012) enlarge microalgae's application for renewable energy generation and wastewater treatment. In BES microalgae and cyanobacteria perform oxygenic photosynthesis, which might be a viable alternative to mechanical aeration. Oxygen is produced in this process by direct biophotolysis, coupled with the simultaneous generation of reduced equivalents, which aids in $\mathrm{CO}_{2}$ sequestration in the presence of light. Electrogenesis, wastewater treatment (through anodic oxidation and cathodic reduction), and $\mathrm{CO}_{2}$ sequestration are added advantages upon algal employment (Rosenbaum et al., 2010). Understanding extracellular electron transport will aid in the optimization of practical applications and the development of innovative BES functionalities. The electron transfer mechanism of novel microalgae strain, Desmodesmus sp. isolated from wastewater was studied in terms of electron transfer mechanisms and applications to improve current production under a variety of circumstances (Wu et al., 2013). With the growing popularity of photosynthetic microalgae, a better understanding of the electron transfer process between the microalgae and the electrode is crucial. Further, a pure algal model is necessary to investigate the interaction for energy generation. In this context, a microalgal strain from the paddy field was characterized in terms of their electrogenic activity in this study to disclose the potentiality of unicellular algae.

\section{MATERIAL AND METHODS}

\section{Sampling}

Algal samples were collected from various aquatic bodies in different districts of Tamil Nadu (Table 1). The water samples collected were immediately transported to the laboratory and proceeded with isolation and the rest were stored at $4{ }^{\circ} \mathrm{C}$.

\section{Isolation and purification of microalgal cultures}

The water samples were serially diluted from $10^{1}$ to $10^{5}$ before being plated on sterile BG11 agar medium. The plates were incubated in an algal growth chamber for 7-10 days, which supports 16h: 8h of light: dark $(1400 \mathrm{~L})$ at a temperature of $28 \pm 2{ }^{\circ} \mathrm{C}$. The growing chamber was illuminated with cold fluorescent lights. To confirm the absence of bacterial and fungal contamination, the colonies were selected and subsequently sub-cultured in BG11 agar plate supplemented with ampicillin $(100 \mathrm{~g} / \mathrm{mLL})$ and kanamycin $(100 \mathrm{~g} / \mathrm{mL})$, cycloheximide $(100 \mathrm{~g} / \mathrm{mL})$. For further analysis, the individual microalgal colonies were cultured in liquid BG 11 media.

\section{Screening for electrogenic activity}

Under an electrochemical work station (AMETEK, scientific instruments, USA), a three-electrode system in Cyclic voltammetry (CV) method was used, with a glassy carbon electrode (3mm diameter) as a working electrode, a platinum wire as a counter electrode, and $\mathrm{Ag} / \mathrm{AgCl}(3 \mathrm{M} \mathrm{KCl})$ as a reference electrode (Wu et al., 2013). A working electrode coated in a concentrated microalgal coat (cell pellet) along with $1 \%$ nafion (binder) was used to investigate the electron transfer process. To stimulate electrode-algae contact, the coated electrode was shade dried and incubated at room temperature $\left(28 \pm 2{ }^{\circ} \mathrm{C}\right)$ for two days. At a scan rate of $10 \mathrm{mVs}^{-1}$, CV traces were obtained in the potential range of -0.8 to $+0.8 \mathrm{~V}$. To verify the lack of oxidation-reduction, deionized water was deoxygenated and utilized as an electrolyte.

\section{RESULTS AND DISCUSSION}

\section{Light microscopic observation of electrogenic microalgae}

Water from various aquatic sources was sampled onto agar plates and the clones were picked after several cycles of agar plate spreading. Sixteen species were isolated and their morphology was observed with light microscope as depicted in figure 1. A brief description of the isolated algal isolates from various sources is presented in table 1 . Isolates with various colony morphology were obtained.

\section{Cyclic Voltammogram analysis}

To assess the redox activity of the algal isolates, CV measurements were carried out on glassy carbon, as they are highly conductive Zittel and Miller, (1965) and measure the current that flows between two electrodes. The pellet from the harvested microalgae on $20^{\text {th }}$ day after inoculation was coated on the 
glassy carbon electrode along with nafion solution to observe the redox peak. CV profile evinced significant variation in electron discharge and generation of energy among the isolates analyzed. In general, nafion serves as cation-exchange polymer through which the single ions or multiple charged ions can pass (Naji et al., 2013) and were reported to promote the actuation response of the electrode (Naji et al., 2016). The electrons from algae could be transferred with the assistance of nafion membrane ensuing the electric power display. The comparable results were obtained by Wang et al., (2014) with the use of nafion membrane in the dual chambered microbial fuel cell.

Six of the 16 isolates were positive for electrogenic activity. The electrogenic activity was observed in Chlorella sp., Chlorococcum sp., Anabena azollae, isolate MDU and isolate ULU from our investigation. However only Hindakia sp. produced a clear redox peak throughout a potential range of -0.8 to $0.4 \mathrm{~V}$ vs $\mathrm{Ag} / \mathrm{Ag} \mathrm{Cl}$, reflecting their redox activity (Figure 2). The electrochemical experiment performed in the culture supernatant (control) displayed only the background current indicating the electrical inactivity, while on the contrary pellets showed a significant response. This represents that no components were exclusively present contributing to the electrogenicity in the cell-free supernatant. Akin to our study, Cereda et al., (2014) have demonstrated the negative response of photocurrent in the fresh medium in which no mediators are contributing to the donation of electrons to the electrode.

The electric response gives forth the current peaks $\left(10^{-6} \mathrm{~A}\right)$ of electro active microalgal strains, Hindakia sp. which produced higher potential peak as shown in Figure 3. In analogy with the results, Wu et al., (2018) have demonstrated the enhanced current generation by electrogenic microalgae Desmodesmus sp. A8. Exoelectrogens are distinguished by their capacity to transport electrons at electrode/biofilm interactions (Meitl et al., 2009), indirect transfer via flavin and direct transfer via proteins (Patil et al., 2012). In electron transfer processes, certain cytochromes of terminal reductases are involved. Wu et al., (2013) reported there was no electrochemical reaction in the supernatant of Desmodesmus sp, certain proteins on the outer membrane, such as cytochromes, may be engaged in direct electron transfer involving in that strain A8 and also reported that Desmodesmus sp. was able to act as a cathodic microorganism. In a cyclic voltammogram Hindakia sp displayed an oxidation peak in the potential range of +100 to $+200 \mathrm{mV}$ which describes its electron releasing capability. The results demonstrate that Hindakia sp. may transfer electrons to an electrode via electro-active proteins on the cellular surface or secreted oxygen. The exploitation of Hindakia sp for electricity generation can be taken up by constructing algal fuel cells. Similarly, in our study, there would be several mechanisms underpinning the electrogenic activity of Hindakia which have to be explored further. Hence following electrochemical analysis, the Hindakia sp. was chosen for further investigation to ensure the power generation.

\section{CONCLUSION}

In this study, the electrogenic activity of Hindakia sp. was analyzed by voltammogram analysis using cyclic voltammetry, which provided a qualitative report on its redox process. This study serves as a step for further construction of bio-electrochemical fuel cell in which Hindakia can be coated in anode which produces electricity by utilization of light energy. Furthermore, since it is a candidature alga their possibility of wastewater utilization as a medium in electrogenesis shall also be explored.

\section{Funding and Acknowledgment}

The authors acknowledge Dr. Pon Pandian, Professor and Head, Department of Nanoscience, Bharathiyar University, Coimbatore for rendering Electrochemical workstation assistance for the analysis, and this research does not hold any funding assistance.

\section{Ethics statement}

No specific permits were required for the described field studies because no human or animal subjects were involved in this research.

\section{Originality and plagiarism}

Authors declare that the contents are original and plagiarism free. 


\section{Consent for publication}

All the authors agreed to publish the content.

\section{Competing interests}

There were no conflict of interest in the publication of this content

\section{Data availability}

All the data of this manuscript are included in the MS. No separate external data source is required. If anything is required from the MS, certainly, this will be extended by communicating with the corresponding author through corresponding official mail; skarthy@tnau.ac.in

\section{Author contributions}

Idea conceptualization, Guidance, reviewing and editing -SK, Experiments and writing original draft - SW, writing original draft- KGT

\section{REFERENCES}

Angelaalincy M, Senthilkumar N, Karpagam R, Kumar GG, Ashokkumar B and P. Varalakshmi. 2017. Enhanced extracellular polysaccharide production and self-sustainable electricity generation for PAMFCs by Scenedesmus sp. SB1. ACS omega., 2(7): 3754-65.

Cereda A, Hitchcock A, Symes MD, Cronin L and TS. Bibby. 2014. A Bioelectrochemical Approach to Characterize Extracellular Electron Transfer by Synechocystis sp. PCC6803. PLoS ONE 9(3): e91484

Chen, R., Li, R., Deitz, L., Liu, Y., Stevenson, R. J., and W. Liao. 2012. Freshwater algal cultivation with animal waste for nutrient removal and biomass production. Biomass Bioenerg., 39: 128-138.

Ferris, M. J., and C. F. Hirsch. 1991. Method for isolation and purification of cyanobacteria. Appl Environ Microbiol., 57(5): 1448-1452.

Kakarla R and B. Min. 2014. Evaluation of microbial fuel cell operation using algae as an oxygen supplier: carbon paper cathode vs. carbon brush cathode. Bioproc Biosyst Eng., 37(12): 2453-61.

Lewis, N. S., and D. G. Nocera. 2006. Powering the planet: Chemical challenges in solar energy utilization. Proc Natl Acad Sci., 103(43): 15729-15735.

Li X, Hu HY, Gan K and YX. Sun. 2010. Effects of different nitrogen and phosphorus concentrations on the growth, nutrient uptake, and lipid accumulation of a freshwater microalgae Scenedesmus sp. Bioresour Technol., 101: 5494- 5500.

Liu, M., Liu, R., and W. Chen. 2013. Graphene wrapped $\mathrm{Cu}_{2} \mathrm{O}$ nanocubes: non-enzymatic electrochemical sensors for the detection of glucose and hydrogen peroxide with enhanced stability. Biosens Bioelectron., 45: 206-212.

Lovley, D. R., and K. P. Nevin. 2011. A shift in the current: new applications and concepts for microbeelectrode electron exchange. Current Opin Biotechnol., 22(3): 441-448.

Medipally, S. R., Yusoff, F. M., Banerjee, S., and M. Shariff. 2015. Microalgae as sustainable renewable energy feedstock for biofuel production. BioMed Res In.t, 519-513.

Meitl, L. A., Eggleston, C. M., Colberg, P. J., Khare, N., Reardon, C. L and L. Shi. 2009. Electrochemical interaction of Shewanellaoneidensis MR-1 and its outer membrane cytochromes OmcA and MtrC with hematite electrodes. Geochimica et Cosmochimica Acta., 73(18): 5292-5307.

Naji, J. A. Chudek, E. W. Abel and R. T. Baker. 2013. Electromechanical behaviour of Nafion-based soft actuators, J Mater Chem B., 1: 2502-2514

Naji, M. Safari and S. Moaven. 2016. Fabrication of SGO/Nafion-based IPMC soft actuators with sea anemone-like Pt electrodes and enhanced actuation performance, Carbon., 100: 243-257

Oh, S. and B. E. Logan. 2005. Hydrogen and electricity production from a food processing wastewater using fermentation and microbial fuel cell technologies. Water Res., 39(19): 4673-4682.

Patil, S. A., Hägerhäll, C., and L. Gorton. 2012. Electron transfer mechanisms between microorganisms and electrodes in bioelectrochemical systems. Bioanal Rev., 4(2): 159-192.

Rajesh, R., Jaivel, N., Prithiva, J. N., and P. Marimuthu. 2020. Studies on Growth Characteristics of Hydrocarbon Producing Botryococus braunii. Madras Agric J., 107(S) 
Rosenbaum, M., He, Z., and L. T. Angenent. 2010. Light energy to bioelectricity: photosynthetic microbial fuel cells. Curr Opin Biotechnol., 21(3): 259-264.

Wu, Y., Guan, K., Wang, Z., Xu, B., and F. Zhao. 2013. Isolation, identification and characterization of an electrogenic microalgae strain. PloS one., 8(9): e73442.

Wu, Y. C., Xiao, Y., Fu, H. Y., and F. Zhao. 2018. Light Affects Electrochemical Characterization of Electrogenic Microalgae Desmodesmus sp. A8. In IOP Conference Series: Earth Environ Sci., 146(1): 012044

Zhou, X., Yuan, S., Chen, R., and R. M. Ochieng. 2015. Sustainable production of energy from microalgae: review of culturing systems, economics, and modelling. $J$ Renew and Sustain Energy., 7(1): 012701.

Zittel H E and F. J. Miller. 1965. A Glassy-Carbon Electrode for Voltammetry. Analytical Chemistry., 37(2): 200-3. 


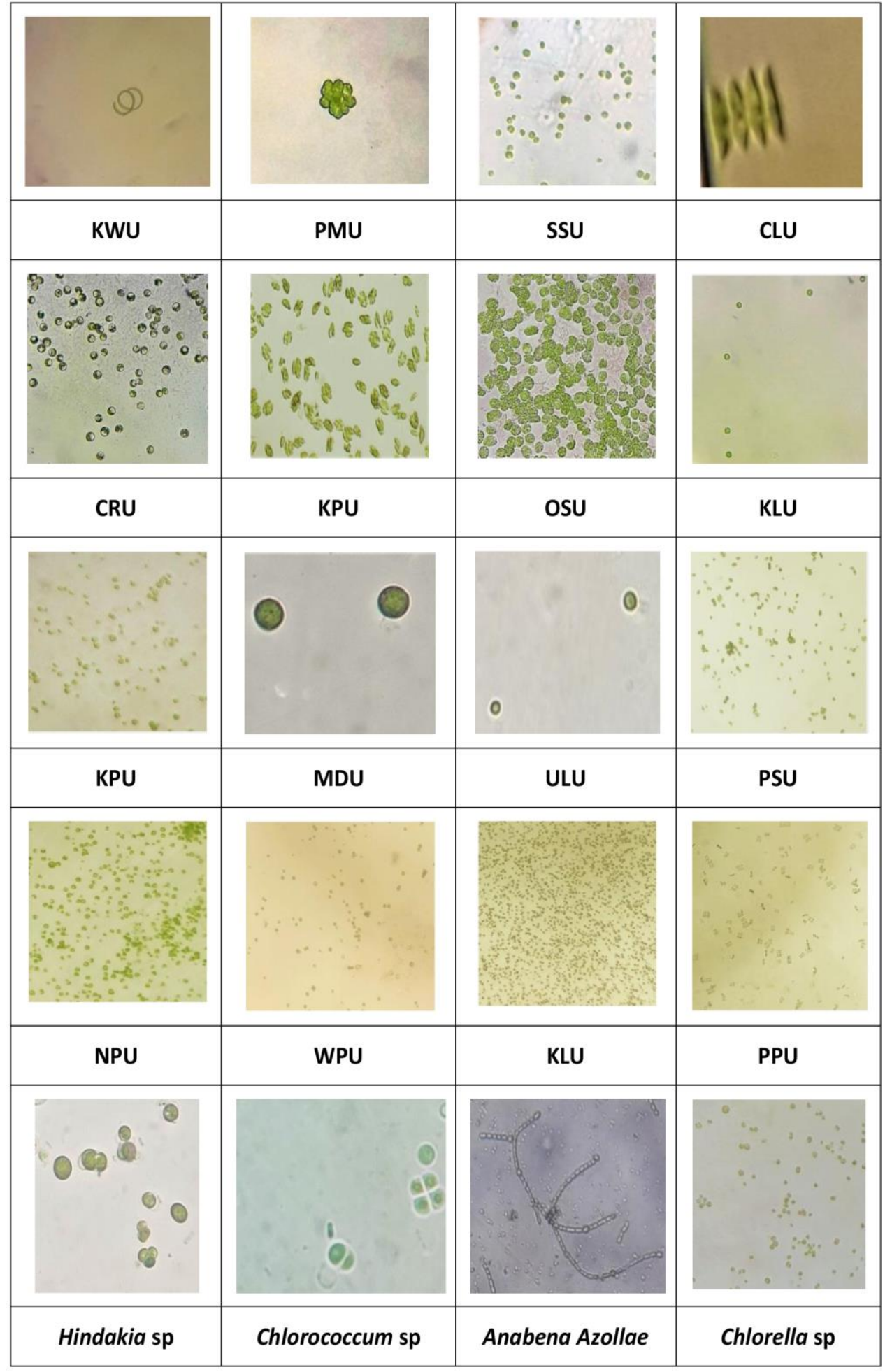

Figure 1. Microscopic images of screened algal isolates under light microscope (250 X) 


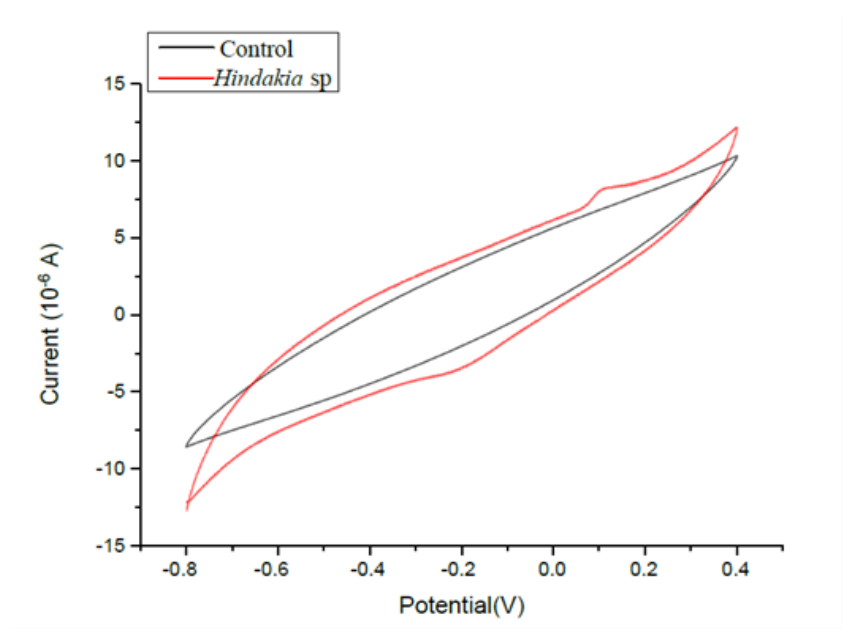

Figure 2. Cyclic voltammograms of Hindakia sp. on glassy carbon under anaerobic condition

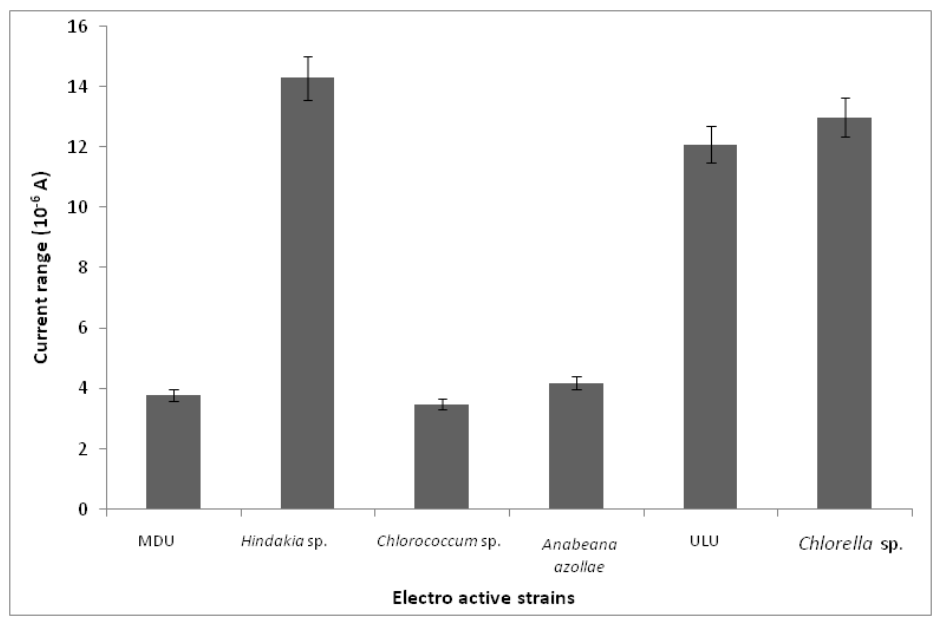

Figure 3. Current peak ranges $\left(10^{-6} \mathrm{~A}\right)$ of electro-active algal strains shown in cyclic voltammograms

Table 1. Brief description on the algal strains

\begin{tabular}{|c|c|c|c|}
\hline Isolate code & Source & Geographical location & Morphological characteristics \\
\hline KWU & Well water & $\begin{array}{l}\text { Keeripatti } \\
\left(11.532937^{\circ} \mathrm{N} / 78.485444^{\circ} \mathrm{E}\right)\end{array}$ & $\begin{array}{l}\text { Unicellular, spiral, solitary and } \\
\text { curved, non-motile }\end{array}$ \\
\hline PMU & $\begin{array}{c}\text { Mangrove } \\
\text { (brackish } \\
\text { water) }\end{array}$ & $\begin{array}{l}\text { Pichavaram } \\
\left(11.417586^{\circ} \mathrm{N} / 79.772133^{\circ} \mathrm{E}\right)\end{array}$ & $\begin{array}{l}\text { Unicellular, spherical, arranged in } \\
\text { clusters, non-motile }\end{array}$ \\
\hline SSU & Sea water & $\begin{array}{l}\text { Samiyarpettai } \\
\left(11.551264^{\circ} \mathrm{N} / 79.759134^{\circ} \mathrm{E}\right)\end{array}$ & $\begin{array}{l}\text { Unicellular, spherical shape, non- } \\
\text { motile and solitary }\end{array}$ \\
\hline CLU & Lake & $\begin{array}{l}\text { Chidambaram } \\
\left(11.406645^{\circ} \mathrm{N} / 79.691559^{\circ} \mathrm{E}\right)\end{array}$ & $\begin{array}{l}\text { Unicellular, flattened, non-motile, } 4 \\
\text { cells arranged in parallel }\end{array}$ \\
\hline CRU & River & $\begin{array}{l}\text { Chengam } \\
\left(12.308555^{\circ} \mathrm{N} / 78.796766^{\circ} \mathrm{E}\right)\end{array}$ & $\begin{array}{l}\text { Unicellular, non-motile, spherical } \\
\text { with vacuole like structure inside the } \\
\text { cell }\end{array}$ \\
\hline KPU & Pond & $\begin{array}{l}\text { Kayambattu } \\
\left(12.305423^{\circ} \mathrm{N} / 78.773261^{\circ} \mathrm{E}\right)\end{array}$ & $\begin{array}{l}\text { Unicellular, oval, non-motile with } \\
\text { folding like structure inside the cell }\end{array}$ \\
\hline OSU & Sewage & $\begin{array}{l}\text { Orathanadu } \\
\left(10.624915^{\circ} \mathrm{N} / 79.250908^{\circ} \mathrm{E}\right)\end{array}$ & $\begin{array}{l}\text { Unicellular, spherical, non-motile } \\
\text { with sac-like structure }\end{array}$ \\
\hline KLU & Lake & $\begin{array}{l}\text { Kulichapattu } \\
\left(10.760682^{\circ} \mathrm{N} / 79.190935^{\circ} \mathrm{E}\right)\end{array}$ & Unicellular, spherical and non-motile \\
\hline
\end{tabular}




\begin{tabular}{|c|c|c|c|}
\hline Isolate code & Source & Geographical location & Morphological characteristics \\
\hline KPU & Pool & $\begin{array}{l}\text { Karungulam } \\
\left(8.634334^{\circ} \mathrm{N} / 77.854799^{\circ} \mathrm{E}\right)\end{array}$ & $\begin{array}{l}\text { Unicellular, spherical, non-motile } \\
\text { with triad arrangement of cells }\end{array}$ \\
\hline MDU & Dam outlet & $\begin{array}{l}\text { Mettur } \\
\left(11.784609^{\circ} \mathrm{N} / 77.802816^{\circ} \mathrm{E}\right)\end{array}$ & $\begin{array}{l}\text { Unicellular, oval, non-motile with } \\
\text { thick outer covering }\end{array}$ \\
\hline ULU & Lake & $\begin{array}{l}\text { Ukkadam } \\
\left(10.982817^{\circ} \mathrm{N} / 76.961144^{\circ} \mathrm{E}\right)\end{array}$ & Unicellular, spherical and non-motile \\
\hline PSU & Pond & $\begin{array}{l}\text { Poosaripalayam } \\
\left(11.004039^{\circ} \mathrm{N} / 76.932391^{\circ} \mathrm{E}\right)\end{array}$ & $\begin{array}{l}\text { Unicellular, ovalshaped, arranged in } \\
\text { either pair or triads }\end{array}$ \\
\hline NPU & Pond & $\begin{array}{l}\text { Nagarajapuram } \\
\left(11.002473^{\circ} \mathrm{N} / 76.912199^{\circ} \mathrm{E}\right)\end{array}$ & $\begin{array}{l}\text { Unicellular, spherical, with oil-like } \\
\text { outer covering }\end{array}$ \\
\hline WPU & Paddy field & $\begin{array}{l}\text { Wetland } \\
\left(11.002288^{\circ} \mathrm{N} / 76.926175^{\circ} \mathrm{E}\right)\end{array}$ & $\begin{array}{l}\text { Unicellular, oval curved, arranged in } \\
\text { tetrads }\end{array}$ \\
\hline KLU & Lake & $\begin{array}{l}\text { Krishnampathy lake } \\
\left(11.004363^{\circ} \mathrm{N} / 76.925233^{\circ} \mathrm{E}\right)\end{array}$ & Unicellular, spherical and solitary \\
\hline PPU & Pond & $\begin{array}{l}\text { Perur } \\
\left(10.964691^{\circ} \mathrm{N} / 76.930098^{\circ} \mathrm{E}\right)\end{array}$ & $\begin{array}{l}\text { Unicellular, spherical, } 8 \text { cells } \\
\text { arranged parallelly to other } 8 \text { cells }\end{array}$ \\
\hline Hindakia sp & & & $\begin{array}{l}\text { Unicellular, spherical, solitary } \\
\text { colonies, non-motile with smooth } \\
\text { cell wall }\end{array}$ \\
\hline $\begin{array}{c}\text { Chlorococcum } \\
\mathrm{sp}\end{array}$ & Paddy field & $\begin{array}{c}\text { Wetland paddy fields } \\
\left(11.002288^{\circ} \mathrm{N} / 76.926175^{\circ} \mathrm{E}\right)\end{array}$ & $\begin{array}{l}\text { Unicellular, tetrad arrangement of } \\
\text { cells }\end{array}$ \\
\hline $\begin{array}{l}\text { Anabena } \\
\text { azollae }\end{array}$ & & & $\begin{array}{l}\text { Chain like arrangement of cells, } \\
\text { heterocystous }\end{array}$ \\
\hline Chlorella sp. & & & Unicellular, spherical and non-motile \\
\hline
\end{tabular}

